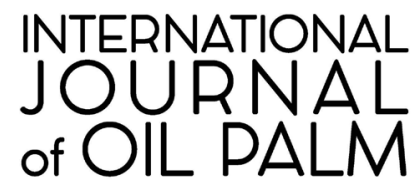

Volume 4, Number 1, 2021

Page 8-21

DOI:10.35876/ijop.v4i1.55

ISSN: 2599-3496 print

ISSN: 2614-2376 online

\title{
Does the Change in Land Cover Alters Birds and Butterflies Diversity?
}

\author{
Marini Machdi Putri*, Yanto Santosa, Burhanuddin Masy’ud
}

IPB University, Bogor 16680, Indonesia

\begin{abstract}
Currently the expansion of oil palm is increasing, which at the same time creates a lot of negative responses related to environmental impacts, biodiversity loss, including birds and butterflies species diversity. Nowadays our understanding of the impacts of oil palm plantations is still based on the claim that oil palm plantations are established on primary forest land. The study aimed to estimate the impact of land cover changes, loss of biodiversity, and possible cohabitation between birds and butterflies based on baseline land type before oil palm plantation. The research was conducted at PT Tempirai Palm Resources, to be precise, in the baseline area (scrubs) and plantation areas planted with oil palm using direct and indirect observation methods. Based on research, it was known that land conversion to oil palm plantations caused changes in the number of species, and the diversity of birds and butterflies. The number of bird species in the baseline area was higher (total species $=22$ species, Shannon-Wiener Diversity Index $=2.51$ ) than in the plantation area. The number of butterfly species in the baseline area was less ( 0 species) than in the oil palm plantation area ( 5 species, Shannon-Wiener Diversity Index=1.56, Margalef Richness Index $=2.23$ ). In general, the increase in bird species' biodiversity was higher (59.09\%) compared to the loss. In contrast, the butterfly species was not lost. A cohabitation also occurred between birds and butterflies at the site. The study concluded that oil palm plantation not only have a negative impact but also a positive impact for biodiversity especially for bird and butterfly.
\end{abstract}

Key words: biodiversity gain, biodiversity loss, cohabitation, impact

\section{INTRODUCTION}

Oil palm (Elaeis guineensis Jacq) is a type of commodity currently being discussed, and there has been a significant increase in the expansion of oil palm. The rise in oil palm plantations has faced accusations or negative campaigns from various parties. The development of oil palm plantations is considered to be eliminating tropical forests in the world. Senior et al. (2012); Edward et al. (2013); and Vijay et al. (2016) also states that the conversion of forest to oil palm has led

\footnotetext{
${ }^{*}$ Corresponding author:

Konservasi Biodiversitas Tropika, Fakultas Kehutanan dan Lingkungan, IPB University, Bogor 16680.

E-mail: marinimachdi@gmail.com
} 
to a major threat to biodiversity and environmental problems. Besides that Kasmiatun (2019) and Nazarreta et al. (2020) also stated that insect abundance is much lower in monocultures of rubber and oil palm than in lowland rainforest.

The expansion of agriculture is one of the most important disturbance factors globally (Chytrý et al. 2009), In contrast to these allegations, oil palm has a positive impact, namely an increase in species diversity, as evidenced in Kartono's research (2015). Koh (2008) stated that butterflies and bird is quite common and in general it is known that it always increases when there is a change in land cover to become oil palm plantations. Based on this, further research is needed to enrich data related to the impacts of land cover changes.

PT Tempirai Palm Resources (TPR) is one of the large oil palm plantations (PSB) in the Palembang area, South Sumatra. This plantation was initially a peat grove so that its existence would cause changes in land cover and negatively impact biodiversity. Birds and butterflies are a family that is the focus of research because they are indicators of decreasing biodiversity due to forest conversion to oil palm plantations (Koh and Wilcove 2008). In their research results, Azhar et al. (2013) stated that oil palm areas with natural undergrowth vegetations would support more bird species and a more significant number. This increase led to the emergence of a cohabitation event. The research objective was to determine the impact of oil palm plantations on bird and butterfly communities and predict the cohabitation between birds and butterflies.

\section{MATERIALS AND METHODE}

\section{Time and Location of Research}

This research was conducted from December 2019 - January 2020 at PT TPR, Ogan Komering Ilir (OKI) Regency, South Sumatra. PT TPR obtained a location permit in 2009 (No.447 / KEP / III / 2009) and the IUP on October 16, 2009 (No. 478/ KEP / D.PERKE / 2009) area of 7500 hectares.

\section{Research Design and Methods}

This study divides land cover into two types, namely the baseline land cover before oil palm plantations are established and land cover after the establishment of oil palm plantations. We used Landsat image analysis one year prior to clearing of plantation land at each location to determine previous land cover types. Data analysis was performed using ArcGIS 10.5. Based on the interpretation of satellite imagery, scrubs represents the baseline or land cover prior to the establishment of oil palm plantations. Based on the land cover analysis, observations were made in the baseline area in the form of scrub, high conservation value areas, and also in areas planted with oil palm in three age classes: young palm, medium palm oil, old palm oil (Figure 1). Oil palm plantations area consist of various ages oil palm tree, there are young tree (1-5 years), medium-sized (11-19 years old), old tree (4-24 years old); and a reserved area for high conservation value (Erniwati et al. 2016).

Data were collected through direct and indirect observations. Bird observation was carried out using the point count method and sound recording. The counting point method is done by determining 5 observation points with a radius of 50 meters which has a distance of 150 meters 


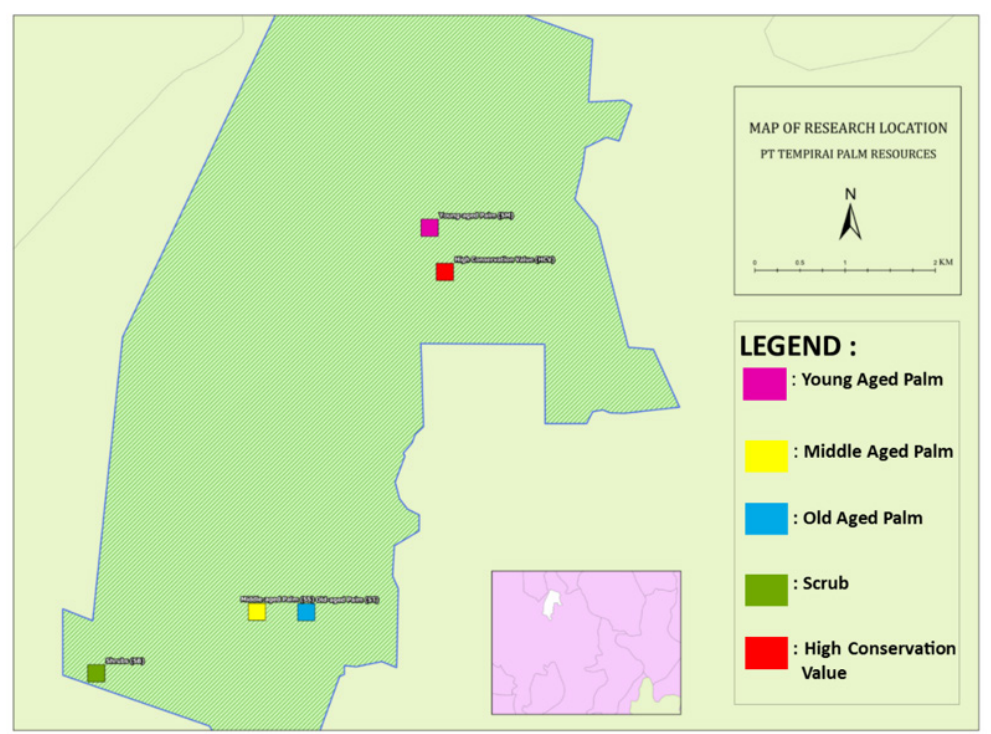

Figure 1 Location of study at PT Tempirai Palm Resources.

between the observation center points, the duration of the observation at one point is carried out for 10 minutes. Point counts remain a popular survey method, and also can be varied including the number of point, the durations and also the radius of the plot (Thompson 2002). In contrast, butterfly observation was carried out using the Pollard transect method (Van-Swaay et al. 2012) with total length of the track is $1 \mathrm{~km}$ and also collected with butterfly traps which is installed 3 pieces in each transect line with a distance of $300 \mathrm{~m}$. This traps being put up in the field as long as the direct observations occur (3 days). Observations were made on each land cover type lane simultaneously, namely in the morning at 06.00-08.00 $\mathrm{AM}$ and evening at 04.00-06.00 PM for birds, and 09.00-12.00 AM for butterflies, with three repetitions everyday. Vegetation analysis is also carried out to identify land cover before and after changes. Vegetation analysis was carried out using a single plot measuring $40 \mathrm{~m} \times 40 \mathrm{~m}(1600$ $\mathrm{m}^{2}$ wide), without repetition. The shape are optimal in obtaining the number of undergrowth species in the measurement and monitoring diversity (Laurance et al.
1998; Nahlunnisa 2016).

\section{Data Analysis}

Impacts of oil palm plantations on bird diversity were determined by comparing the current biodiversity found on each plantation covers, with those found on the current baseline (with an assumption that the current baseline resembles the previous land cover before the plantation establishment). Data analysis was performed using excel calculations. The data analysis used to answer the research objectives is presented in Table 1.

\section{RESULT AND DISCUSSION}

\section{Diversity of Undergrowth Species}

Vegetation analysis was carried out to determine the condition of land cover before and after turning into oil palm plantations, especially the condition of undergrowth species diversity in each location, so that it can be seen whether there is a reduction in biodiversity after changes in land cover. Based on the vegetation analysis results, it was known that each land cover in the location has a variety of plant 
Table 1 Data analysis

\begin{tabular}{|c|c|}
\hline Objective & Data Analysis \\
\hline $\begin{array}{l}\text { To estimate the impact of land } \\
\text { cover changes the number of } \\
\text { species and the diversity index } \\
\text { for birds and butterflies, and to } \\
\text { identify vegetation types }\end{array}$ & $\begin{array}{l}\text { Number of birds and butterflies, Shannon Wiener } \\
\text { diversity index, Evenness Index, Margalef species } \\
\text { richness index, number of species } \\
\text { Shannon Wiener diversity index, Evenness Index, } \\
\text { Margalef species richness index }\end{array}$ \\
\hline $\begin{array}{l}\text { To predict the magnitude of bio- } \\
\text { diversity loss or biodiversity gain } \\
\text { due to changes in land cover }\end{array}$ & $\begin{array}{l}\text { Sorensen similarity index, calculation of the per- } \\
\text { centage loss-gain (Yudea 2019) }\end{array}$ \\
\hline $\begin{array}{l}\text { To identify the possible cohab- } \\
\text { itation and overlapping niches } \\
\text { between birds and butterflies in } \\
\text { oil palm plantations }\end{array}$ & $\begin{array}{l}\text { Bird guild classification, degree of association (Jac- } \\
\text { card Index), Smith formula of ecological niche anal- } \\
\text { ysis (FT), Niche overlap analysis (Morisita Index) }\end{array}$ \\
\hline
\end{tabular}

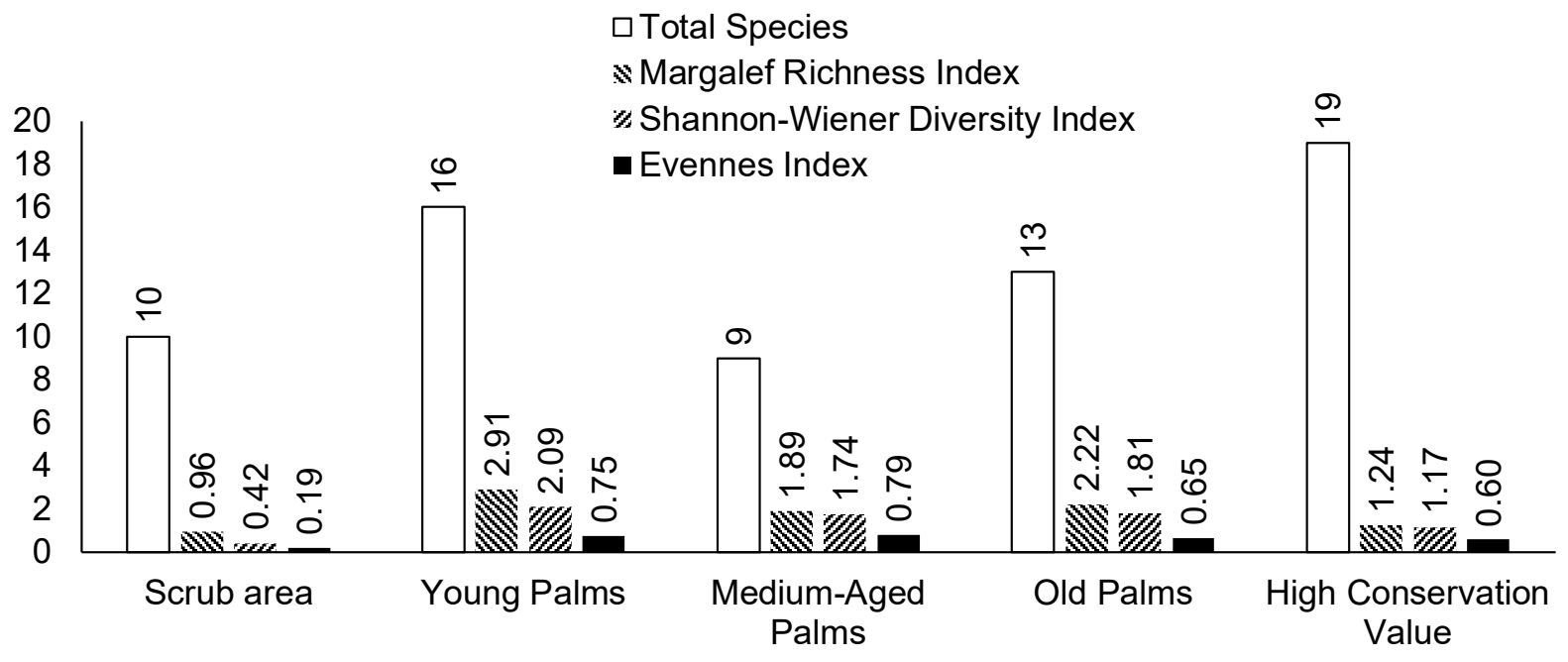

Figure 2 Number of species, richness index value, diversity, and evenness of undergrowth species in PT Tempirai Palm Resources.

species. The complete data on the number of undergrowth species for each land cover type is presented in Figure 2. The number of the baseline land cover found was ten species, while the land cover planted with oil palm has a higher number of plant species consisting of gardens. There were 16 undergrowth types of young palms, nine types of medium-aged palms, 13 types of old palms, and 19 species in the high conservation value area indicated that in the areas planted with oil palm, maintenance activities are carried out to remove weeds.

Changes in land cover from scrub to oil palm plantation areas would also impact plant species composition aspects, probably due to the types of plants that appear and the types of lost plants. Changes in this plant species' composition are reflected in the magnitude of the Sorensen Similarity Index or Community Similarity Index. Compared with the baseline area, plant species composition 
in the area planted with oil palm is classified as different. high conservation value areas had a higher similarity index value with medium-aged palms and old palms areas than other areas. This is because the conditions in the medium-aged palms and old palms areas which have a variety of undergrowth and almost the same conditions as the high conservation value area. While the young palms and scrub areas only had a few undergrowth as a result of waterlogged conditions (scrub area) or because they were newly planted (young palms). The Old palms area area has small plant species in common with other oil palm areas as a result of intensive weed cleaning so as not to disturb the oil palm plantations. this makes the similarity value smaller. The difference in species composition can be seen from the low value of community similarity presented in Table 2.

Changes in land cover to oil palm plantations generally lead to an impact in plant species (Figure 3 ). The number of undergrowth species which is loss and gain, it is determined by comparing the current undergrowth species found on all plantation covers, with those found on the current baseline. The types of plants that are loss such as: Digitaria ciliaris, Scleria sumatrensis, Scirpodendron gaeri and
Cyperus haspan. The example of gained plants species such as Dianella ensifolia, Axonopus compresus, Nephentes $\mathrm{sp}$. The change in land cover, which was originally in the form of inundated shrublands, has caused the loss and increase of undergrowth species. Undergrowth will be easier to grow in areas that are not inundated by water. The increase in the number of plant species is not different from the research results of Kwatrina et al. (2018) in several large oil palm plantations in Central Kalimantan, where the value of increasing plant species ranged from $23-100 \%$ due to changes from scrub to oil palm plantations.

\section{Estimation of the Loss and Gain of Bird and Butterfly Species}

The number of birds found at the research location was 41 bird species (Figure 4). The species of birds found were scattered on each land cover. Examples of bird species found at the research location include the Ixobrychus flavicollis, Ardea spesiosa, and Egretta garzetta. This species of bird was identified as waterbird class as well as fish eaters (Piscivora). Presumably, each location has a canal that became a feed source in the form of small fish or benthic macrozoids. The baseline area, which is the

Table 2 Value of the similarity index of plant communities in PT Tempirai Palm Resources

\begin{tabular}{lccccc}
\hline Land coverage type & Scrub area & $\begin{array}{c}\text { Young } \\
\text { palms }\end{array}$ & $\begin{array}{c}\text { Medium-aged } \\
\text { palms }\end{array}$ & Old palms & $\begin{array}{c}\text { High conserva- } \\
\text { tion value }\end{array}$ \\
\hline Scrub area & 1 & 0.32 & 0.18 & 0.11 & 0.13 \\
\hline Young palms & 1 & 0.64 & 0.40 & 0.17 \\
\hline Medium-aged palms & & 1 & 0.48 & 0.30 \\
\hline Old palms & & 1 & 0.38 \\
\hline High conservation value & & & 1 \\
\hline
\end{tabular}




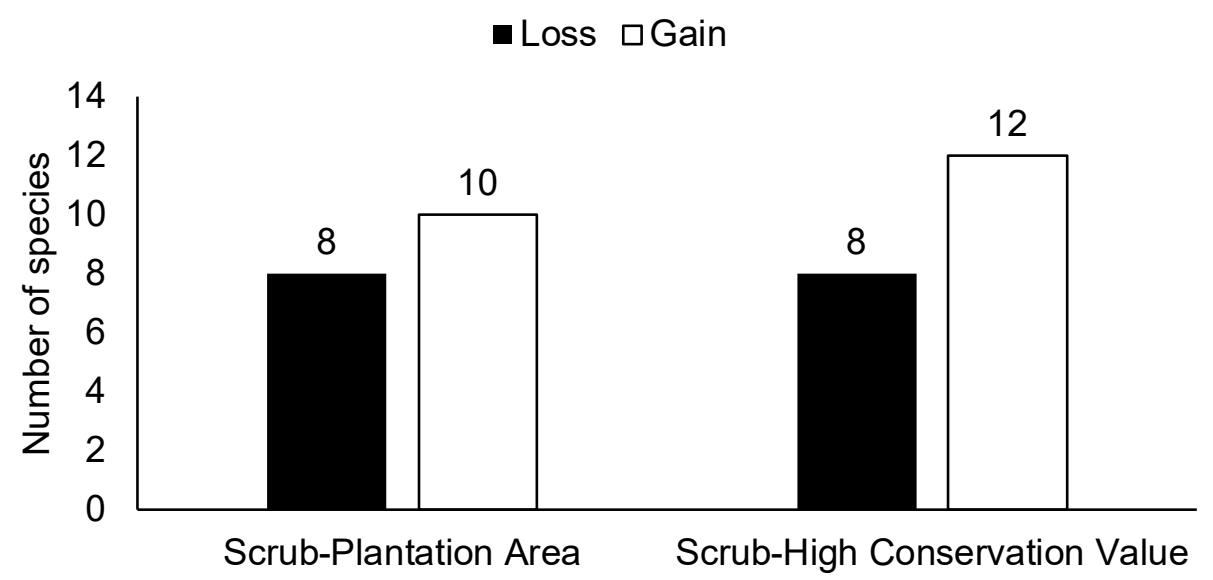

Figure 3 Comparison of the loss-gain value of plant biodiversity at PT Tempirai Palm Resources.

initial description of the land, has a relatively large number of species, namely 27 types, and tends to be more than the land cover planted with oil palm (Plantation area). Number of species which is shown in tabel plantation area (total) is calculated by counting species which found in young palms, medium-aged palms and old palms. The types of birds identified in the study varied based on their feed types, including carnivores, insectivores, and frugivores.

Meanwhile, butterflies were not found in the scrub area of PT TPR, but in the high conservation value area and areas planted with oil palm, there were butterflies with a range of 1-5 species. The most common family is Nymphalidae (5 species). While the family that was found the least was the Lycanidae family (1 species). Eurema hecabe from the family Pieridae is the species with the largest number of individuals (12 individuals), which is calculated by counting individuals encountered in young palms, medium-aged palms, old palms.

The value of the diversity index for birds and butterflies on each type of land cover in the research location shows different values. The baseline area has a lower richness index value and species diversity than the total oil palm area and the high conservation value area. The richness index indicates the number of species in a community. The greater the number of species found, the greater the richness index. According to Wahyuni et al. (2014), species richness showed the number of species found in a location with the number of species found. The area planted with oil palm as a whole has a lower index value than the shrub area. This result is in line with the number of species. Shrub is a good habitat for some species of birds to perch and look for food on the scrub area. The denser the cover of the undergrowth, birds will be easier in hiding and looking for food, this condition can increase bird diversity. As stated by reference Hinsch (2013) and Azhar et al. (2011), the increase in ground vegetation cover can marginally increase bird and butterfly diversity in plantations, and provide habitat for benefical natural pest control.

Changes in land cover also affected the diversity of butterfly species in the location. The land cover in high conservation value areas has a higher number of species and individuals than land cover in oil palm, namely five types from 3 families with nine individuals. The species found in 


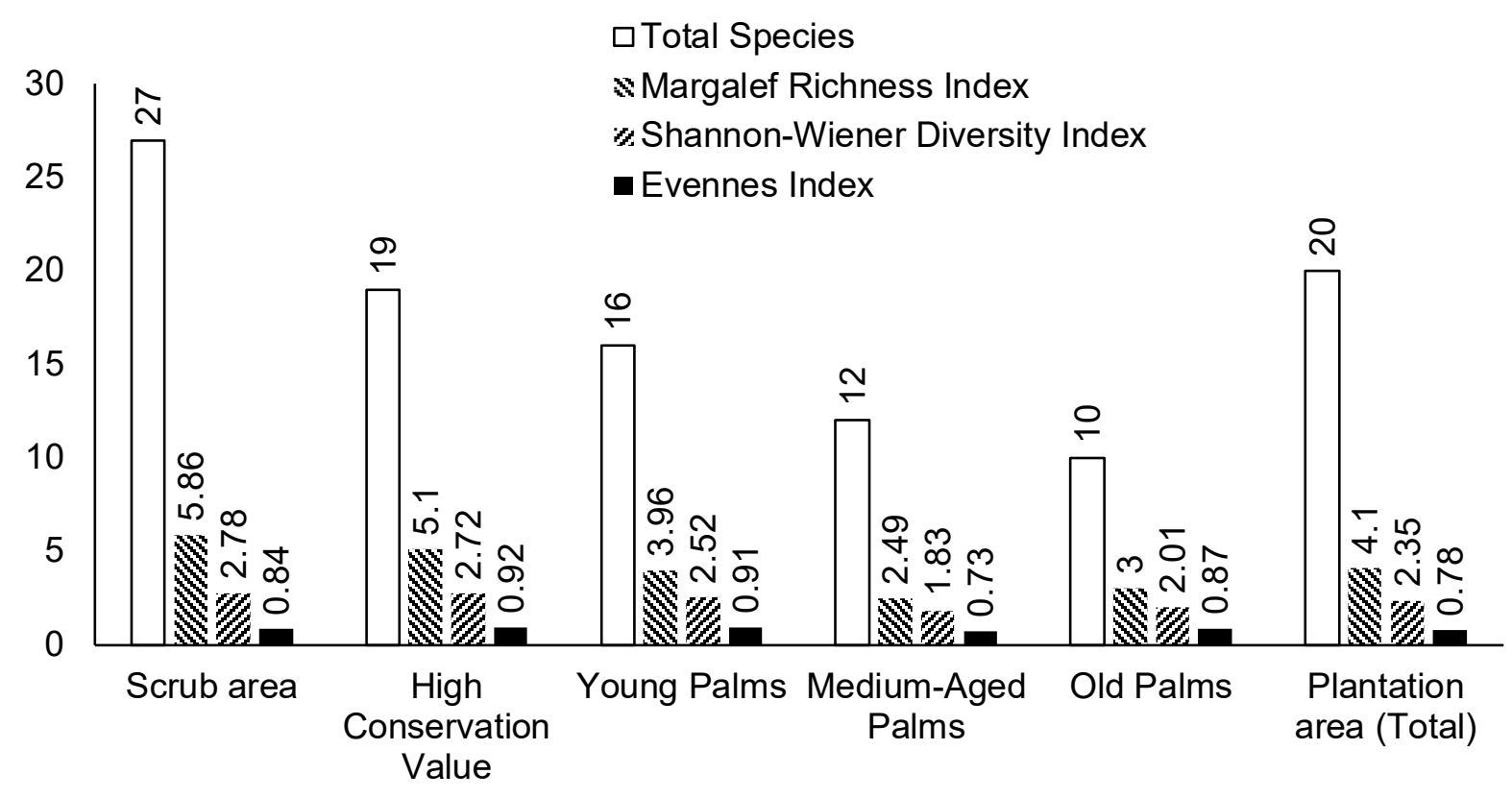

A

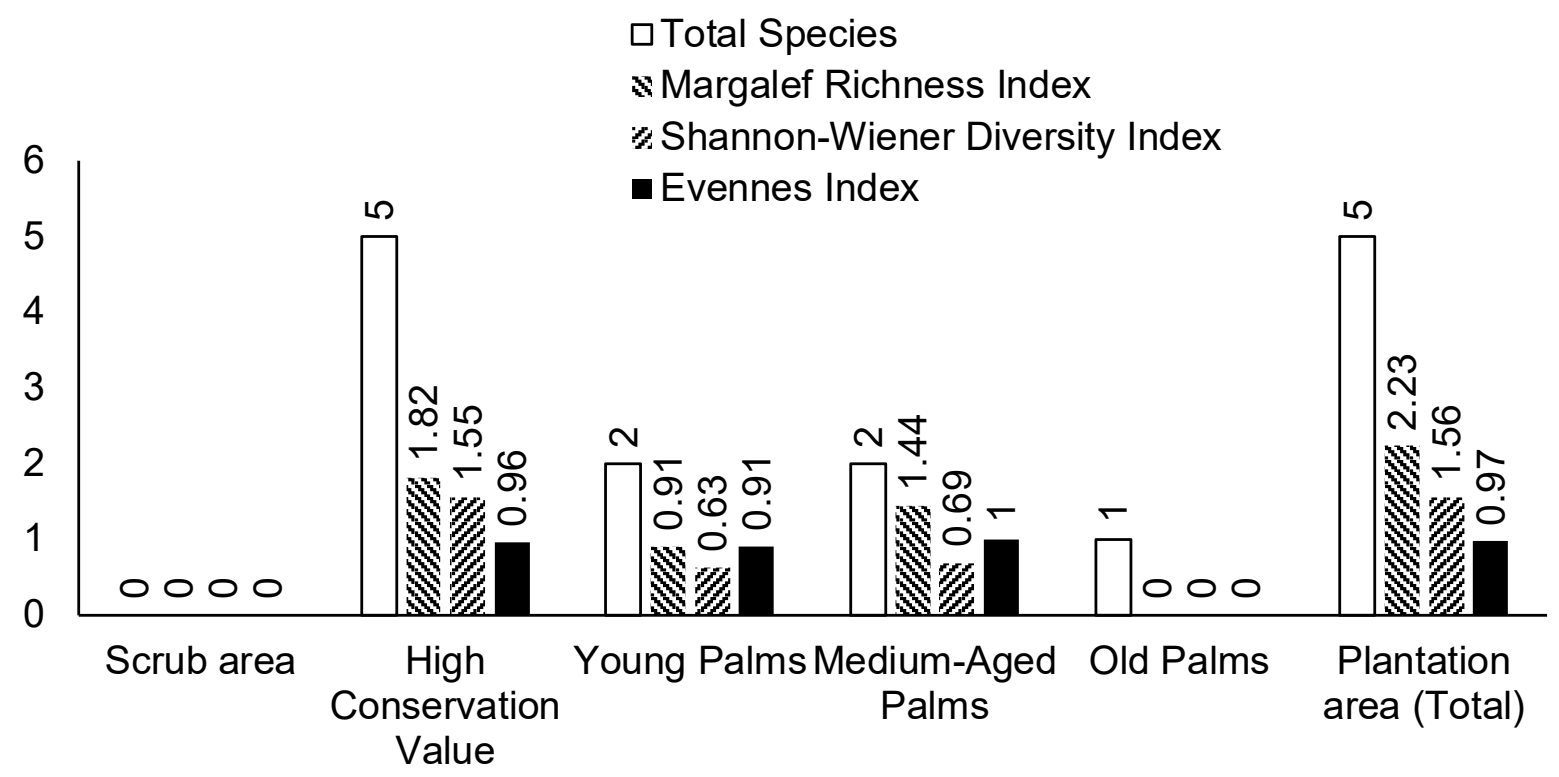

B

Figure 4 Number of species, species richness index, diversity index, and evenness index (a) birds (b) butterflies at PT Tempirai Palm Resources.

the high conservation value area include Eurema hecabe, Leptosia nina, Danaus affinis, and Pelopidas conjunctus. Eurema hecabe butterflies from the family Pieridae are found in many high conservation value areas with four individuals.
The species found in PT TPR were mostly from the Nymphalidae family.

Another thing that also caused this family to be encountered quite often was that Nymphalids have a high ability to live. After all, they are polyphagous (having 
more than one type of host plant). The Nymphalidae family's abundant existence can also be caused by the large availability of food sources in their habitat and also its ability to adapt (Majumder et al. 2003; Widhiono 2015; Koneri et al. 2019). Butterflies have different habitat specifications from general to specific (Putri 2016).

The study showed that bird and butterfly species distribution tends to be evenly distributed because the evenness index value is close to one. If the evenness index obtained for each taxon showed a value close to one, it indicates that the animals are evenly distributed in the location. There are no dominant types (Rahayu 2012; Gaunle 2018). A species with a high level of stability has a greater chance of preserving its species (Mawazin and Subiakto 2013). The high value of fairness indicates that this location have sufficient feed to meet the needs of the birds and the absence of competition that led to the emergence of a dominant species.

The subsequent analysis to determine the impact of oil palm plantations is an analysis of communities' similarity in each land cover to determine whether birds and butterflies' composition between before and after land cover changes is different (Table 3). The difference in composition between land covers affected the survival types of butterflies.

Based on the data presented in Table 3 , it can be seen that the similarity level of bird and butterfly communities in the PT TPR location tends to below since the majority index value below 0.5 . Environmental conditions determine community

Table 3 Community similarity index of birds and butterflies at PT Tempirai Palm Resources.

\begin{tabular}{|c|c|c|c|c|c|c|}
\hline Birds & $\begin{array}{l}\text { Scrub } \\
\text { area }\end{array}$ & $\begin{array}{l}\text { High con- } \\
\text { servation } \\
\text { value }\end{array}$ & $\begin{array}{l}\text { Young } \\
\text { palms }\end{array}$ & $\begin{array}{l}\text { Medium-aged } \\
\text { palms }\end{array}$ & $\begin{array}{c}\text { Old } \\
\text { Palms }\end{array}$ & $\begin{array}{c}\text { Plantation } \\
\text { area (Total) }\end{array}$ \\
\hline Scrub area & & 0.43 & 0.51 & 0.46 & 0.48 & 0.55 \\
\hline High conservation value & & & 0.51 & 0.51 & 0.48 & 0.56 \\
\hline Young palms & & & & 0.64 & 0.61 & 0.88 \\
\hline Medium-aged palms & & & & & 0.45 & 0.68 \\
\hline Old Palms & & & & & & 0.66 \\
\hline \multicolumn{7}{|l|}{ Plantation area (Total) } \\
\hline Butterflies & $\begin{array}{l}\text { Scrub } \\
\text { area }\end{array}$ & $\begin{array}{l}\text { High con- } \\
\text { servation } \\
\text { value }\end{array}$ & $\begin{array}{l}\text { Young } \\
\text { palms }\end{array}$ & $\begin{array}{l}\text { Medium-aged } \\
\text { palms }\end{array}$ & $\begin{array}{c}\text { Old } \\
\text { Palms }\end{array}$ & $\begin{array}{c}\text { Plantation } \\
\text { area (Total) }\end{array}$ \\
\hline Scrub area & & 0 & 0 & 0 & 0 & 0 \\
\hline High conservation value & & & 0 & 0.29 & 0 & 0.10 \\
\hline Young palms & & & & 0 & 0 & 0.57 \\
\hline Medium-aged palms & & & & & 0 & 0.57 \\
\hline Old Palms & & & & & & 0.33 \\
\hline Plantation area (Total) & & & & & & \\
\hline
\end{tabular}


similarity between land covers when it has almost the same land cover condition. The higher the probability that it will have the same type of species. Koneril and Saroyo (2011) stated that different habitats have low species similarity, and the same habitat will have higher species similarity than different habitats. Based on the table below, it can be seen that the bird species found in the baseline area and the area planted with oil palm tended to be the same, while the butterfly species found were different. Based on this index, it can be said that changes in land cover to oil palm have not caused significant changes in bird habitat.

Various factors can cause the loss or increase in bird and butterfly species due to changes in land cover conditions. However, bird species are missing. But there are also bird species found so that it can be expected to maintain the balance of the ecosystem. The comparison between the estimated loss-gain value of bird

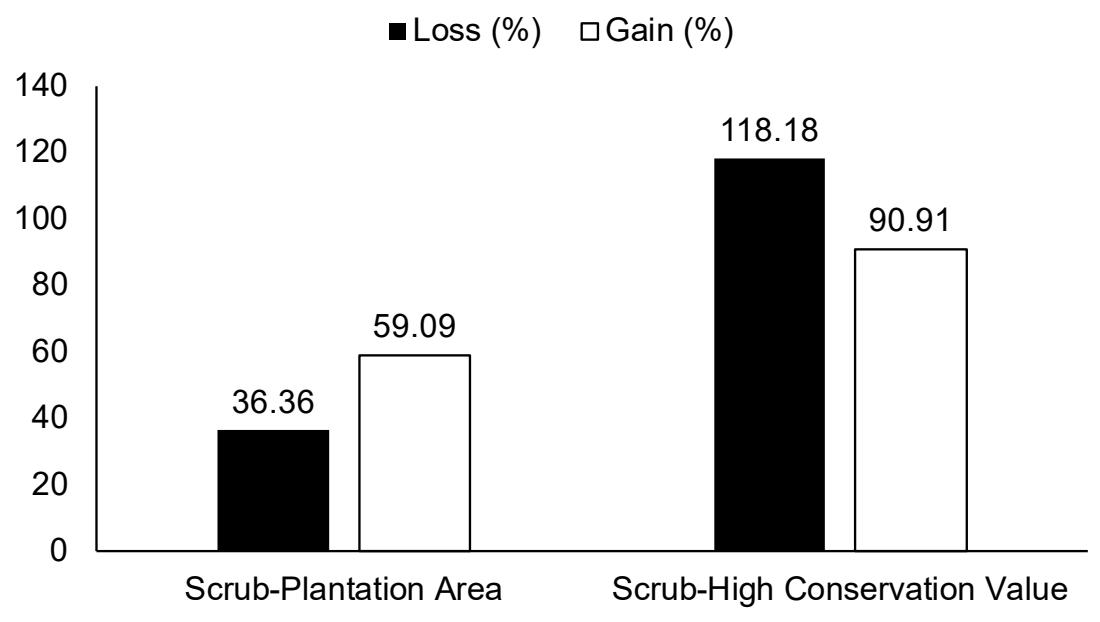

A

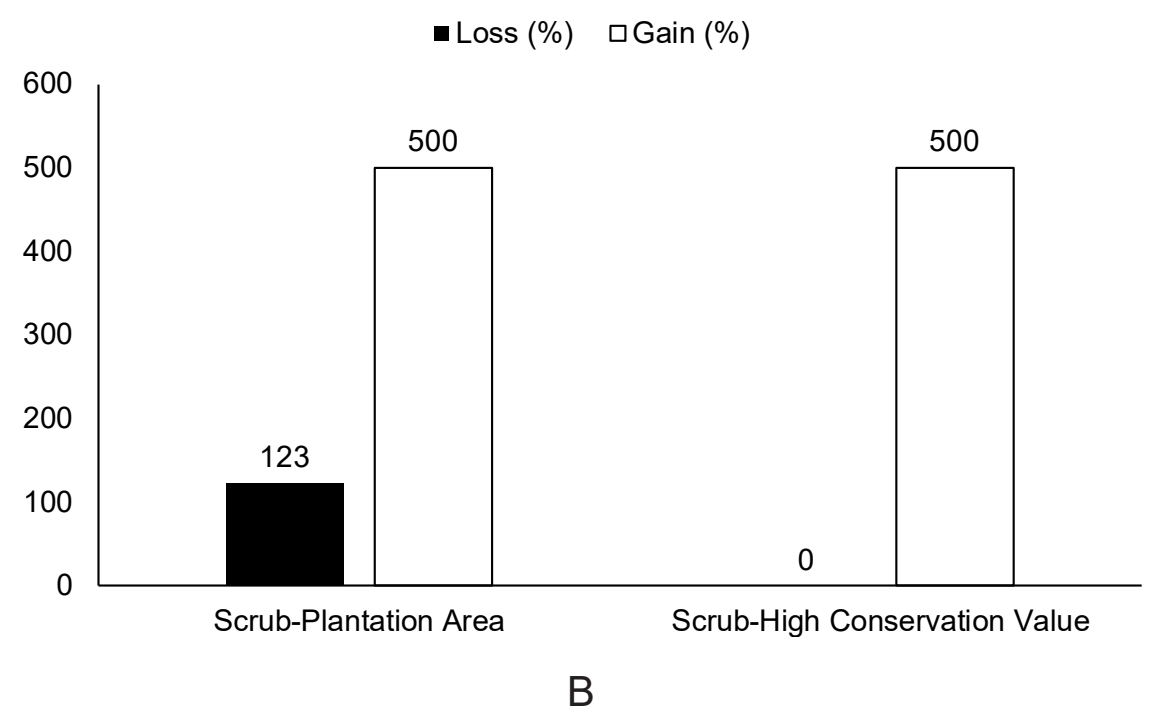

Figure 5 Loss-gain comparison of (A) birds (B) butterflies at PT Tempirai Palm Resources. 
species at the location can be seen in Figure 5. Changes in land cover between the SB-Plantation Area had a higher species gain value $(59.09 \%)$ than the loss value $(36.36 \%)$. This number shown that the bird species were loss is lower than the species were gain, which which means that oil palm plantation land can still be suitable habitat for the species of birds that are in the location.

Unlike the case with birds, as a result of the absence of butterfly species in the baseline area, the number of butterfly species acquired at the site reaches $500 \%$ (Figure 5b). The percentage of butterfly gain in this species seems significant due to the effect of not finding butterfly species in the baseline area. the baseline area is not able to provide the resources that can be used by butterflies to survive. The gain of these types cannot replace the lost types, but it has a considerable impact on species diversity in the PT TPR plantation area. It can replace the ecological role of the missing species. The composition of butterfly and bird species comprise of the species gain, and species loss indicated a change in natural resources available in the scrub replace by oil palm plantation. This situation leads to species being lost due to changing the availability of resources, and to survive due to a wide spectrum of food sources and high adaptability (Edwards et al. 2013).

\section{Estimation of Cohabitation Between Birds and Butterflies}

The value of using the same resource by both taxa based on ecological data is called species affinity. Based on the calculation, it is known that the degree of association in the PT TPR area is 0.83 . The closer to number 1 , it can be interpreted that the preferences about food and habitat of the two animal taxa tend to be the same. The high value of the degree of this association is because in this study butterflies and birds are found in the same type of land cover Therefore, the potential for interspecific competition between the two taxa is also enormous.

Next is the calculation of the ecological niche of butterflies and birds based on feed resources. Apart from this, food niches can also indicate food selectivity (Krebs 1978) since the feed resources are the basic needs of living things. The calculation of the area of the niche is based on the Smith formula. The more the FT value is closer to the 0 value, the more specialist the species is. The area of ecological niches that are almost identical between bird species and butterflies indicates overlapping due to the narrow environmental condition. Table 4 is the result of the calculation of the ecological niche area of each taxon at the two observation locations.

One of the similarities in the use of niches seen during the research activities was the sharing of existing flowering plants such as Turnera ulmifolia and some scrub. One type of bird that often uses this type of plant as a food source is the honey substitute (Cinnyris jugularis). This bird is usually found in areas that provide a lot of shrubs, especially those that flower.

Based on this table, it can be seen that the calculation of overlapping niches using the Morisita index obtained values ranging from 0-0.999 with an overlap percentage between $0-18.518 \%$ in PT TPR

Table 4 Area of butterfly and bird ecological niches at PT Tempirai Palm Resources.

\begin{tabular}{lc}
\hline Taxon & Niche area (FT) \\
\hline Butterfly & 0.30 \\
\hline Bird & 0.41 \\
\hline
\end{tabular}


Table 5 Percentage of niche overlap in PT TPR

\begin{tabular}{llcc}
\hline Resources & Location & $\begin{array}{c}\text { Overlapping } \\
\text { niche index }(\mathrm{Ch})\end{array}$ & $\begin{array}{c}\text { Percentage of } \\
\text { overlap niche (\%) }\end{array}$ \\
\hline Food & & 0.9551 & 12.50 \\
\hline Space & Young Palms & 0.8325 & 5.18 \\
\cline { 2 - 4 } & Medium-aged Palms & 0.8989 & 4.44 \\
\cline { 2 - 4 } & Old Palms & 0.6575 & 1.85 \\
\cline { 2 - 4 } & High Conservation Value & 0.9999 & 17.59 \\
\cline { 2 - 4 } & Scrub Area & 0 & 0 \\
\cline { 2 - 4 } & Plantation area (Total) & 0.9979 & 18.52 \\
\hline
\end{tabular}

(Table 5). The Morisita index was chosen because it is the best index and is not affected by repetition. Each species of birds and butterflies found in the study area has its type of feed. However, various kinds of birds use the same resources like food and space as butterflies. Butterflies can be found in all areas in the TPR area except in scrub areas. Thus the birds found in the site do not have to share space with butterflies, so there is no cohabitation in the area.

About 5 types of plants are used together for food by birds and butterflies from 19 plants found. The plants used are Imperata cylindrica (Poaceae), Oryza sp. (Poaceae), and Scleria sumatrensis (Cyperaceae). Seed-eating birds use these plants to meet their feed needs. Also, butterflies use these plants to be used as food plants and as hosts. The types of butterflies that utilize the I. cylindrica plant include butterflies from the Hesperiidae family and butterflies from the Ypthima philomela and $Y$. baldus (Nymphalidae) species.

The results showed overlapping niches between the two taxa types, but the existing species persisted and indicated that the two species had identical ecological niches. It means that some resources are used together, and other resources are used separately. Although there are over- lapping niches, competition does not necessarily occur. It occurs when resources are limited among these species, they will tend to use different foraging strategies in order to decrease potential competition (Ballejo 2018). The utilization of resources simultaneously includes the use of feed resources and provides for the benefit of space.

\section{CONCLUSION}

Changes in land cover to oil palm plantations led to changes in the number of species and the diversity of birds and butterflies in PSBs. The number of bird species in the PT TPR baseline area was higher (22 species, Shannon-Wiener diversity index $=2.51$; Margalef Richness index $=4.86$ ) compared to the plantation area (total species $=20$ species) and high conservation value area (19 species, Shannon-Wiener diversity index $=2.72$; Margalef Richness index $=5.1$ ). There were no butterfly species found in the baseline area, while in the oil palm plantation area, 5 types of butterflies were found (total species $=5$ species; Shannon-Wiener diversity index $=1.56$; Margalef Richness index $=2.23$ ). 5 types of butterflies also found on high conservation value area (total species $=5$ species; Shannon-Wiener diversity index $=1.55$; 
Margalef Richness index $=1.82$ ).

There is biodiversity loss and biodiversity gain due to changes in land cover from shrubs to oil palm plantations and high conservation value. In general, bird species' gain value in the plantation area was higher $(59.09 \%)$ than the loss value. Meanwhile, there was no loss of butterfly species in location, and there was a butterfly species gain of $500 \%$. There is cohabitation between birds and butterflies in the oil palm plantation areas, namely food, and space. There was an overlap in the ecological niches between birds and butterflies in the oil palm plantation areas with an overlap rate of $1.85 \%-18.518 \%$.

\section{SUGGESTION}

Further research needs to be carried out to determine the potential for restoration of plantation land and conducted on various types of baseline areas of oil palm plantations and multiple taxa.

\section{ACKNOWLEDGEMENTS}

Special thanks to staff at PT Tempirai Palm Resources who help collected data along this project.

\section{REFERENCES}

Azhar B, Lindenmayer DB, Wood J, Fischer J, Manning A, McElhinny C, Zakaria M. 2011. The conservation value of oil palm plantation estates, small holdings and logged peat swamp forest for birds. Forest Ecol Manag. 262(12):2306-2315.

Azhar B, Lindenmayer DB, Wood J, Fischer J, Manning A, McElhinny C, Zakaria M. 2013. The influence of agricultural system, stand cultural complexity and landscape context on foraging birds in oil palm landscapes. Ibis. 155(2):297312.

Ballejo F. Lambertucci SA, Trejo A, De santis LJM. 2018. Trophic niche overlap among scavengers in Patagonia supports the condor-vulture competition hypothesis. Bird Conserv Int. 28(3):390-402.

Chytrý M, Pyšek P, Wild J, Pino J, Maskell LC, Vilà M. 2009: European map of alien plant invasions based on the quantitative assessment across habitats. Divers Distrib. 15:98-107.

Edwards FA, Edwards DP, Hamer KC, Davies RG. 2013. Impacts of logging and conversion of rainforest to oil palm on the functional diversity of birds in Sundaland. Ibis. 155(2):313-326.

Erniwati, Zuhud EAM, Santosa Y, Anas I. 2016. The value of secondary forest patches for birds conservation in palm oil landscapes of Riau, Sumatra. Biodiversitas. 17(2):791798.

Gaunle K. 2018. How to Calculate Species Evenness. [Internet]. [Cited 13 Mei 2021]. Available from: http://sciencing.com/calculate-species-evenness-2851.html.

Hinsch, J. 2013. Substituting Pesticides With Biodiversity - The Potential for Biocontrol in Oil Palm Plantations. Copenhagen (DK): University of Copenhagen.

Kartono AP. 2015. Keragaman dan kelimpahan mamalia di perkebunan sawit PT Sukses Tani Nusasubur Kalimantan Timur. Media Konservasi. 20(2):85-92. Kasmiatun, Nazarreta R, Hidayat P, Buchori D. 2020. Diversity and species composition of click beetles (Coleoptera: Elateridae) at different land-use types in Harapan Rainforest landscape, 
Jambi, Indonesia. IOP Conf Series: Earth Environ Sci. 468: 12-15.

Koh LP. 2008. Can oil palm plantations be made more hospitable for forest butterflies and birds?. J Appl Ecol. 45: 1002-1009.

Kohl LP, Wilcove DS. 2008. Is oil palm agriculture really destroying tropical biodiversity ?. Conserv Lett. 1:60-64.

Koneri R, Nangoy MJ, Siahaan P. 2019. The abundance and diversity of butterflies (Lepidoptera: Rhopalocera) in Talaud Islands, North Sulawesi, Indonesia. Biodiversitas. 20 (11):3275-3283.

Koneril R, Saroyo. 2011. Distribusi dan keanekaragaman kupu-kupu (lepidoptera) di gunung manado tua, kawasan taman nasional laut bunaken, Sulawesi Utara. J Bumi Lestari. 12(2):357-365.

Krebs CJ. 1978. Ecology: The experimental analysis of distribution and abundance. New York (US): Harper and Row Publ.

Kwatrina RT, Santosa Y, Bismark M, Santoso N. 2018. Ecological impacts of oil-palm plantation on butterfly and bird species diversity. Manajemen Hutan Tropika. 24(1):23-31.

Laurance WF, Ferreira LV, Rankin de Merona JM, Hutchings RW. 1998. Influence of plot shape on estimates of tree diversity and community composition in Central Amazonia. Biotropica. 30(4):662-665.

Majumder J, Lodh R, Agarwala BK. 2013. Butterfly species richness and diversity in the Trishna wildlife sanctuary in South Asia. 13(79). J Insect Sci. 13(79).

Mawazin, Subiakto A. 2013. Keanekaragaman dan komposisi jenis permudaan alam hutan rawa gambut bekas tebangan di Riau. Indones Forest Rehabil J. 1(1):59-73.
Nahlunnisa H. 2016. Keanekaragaman spesies tumbuhan di areal nilai konservasi tinggi (nkt) perkebunan kelapa sawit provinsi riau. Media Konservasi. 21(1):91-98.

Nazarreta R, Hartke TR, Hidayat P, Scheu S, Buchori D, and Drescher J. 2020. Rainforest conversion to smallholder plantations of rubber or oil palm leads to species loss and community shifts in canopy ants (Hymenoptera: Formicidae). Myrmecol News. 30:175-186.

Putri IASLP. 2016. Pengaruh aktivitas pariwisata terhadap keragaman jenis dan populasi kupu-kupu di taman nasional Bantimurung Bulusaraung. JPHKA. 13(2):101-118.

Rahayu SE, Basukriadi A. 2012. Kelimpahan dan Keanekaragaman Spesies Kupu-Kupu (Lepidoptera; Rhopalocera) Pada Berbagai Tipe Habitat di Hutan Kota Muhammad Sabki Kota Jambi. Biospecies. 5(2):40-48.

Senior MJM, Hamer KC, Bottrell S et al. 2013. Trait-dependent declines of species following conversion of rain forest to oil palm plantations. Biodivers Conserv. 22: 253-268.

Thompson F, Burhans D, Brian R. 2002. Effects of point count protocol on bird abundance and variability estimates and power to detect population trends (el efecto de protocolo de conteo de puntos en la abundancia y estimado de variabilidad de aves y el poder, para detectar tendencias poblacionales). J Field Ornithol. 73(2):141-150.

Van Swaay C, Brereton T, Kirkland P, Warren M. 2012. Manual for Butterfly Monitoring. Netherlands (NL): De Vlinderstichting.

Vijay V, Pimm SL, Jenkins CN, Smith SJ. 2016. The impacts of oil palm on recent 
deforestation and biodiversity loss. Widhiono I. 2015. Diversity of butterflies PLOS ONE. 11(7). in four different forest types in Mount Wahyuni, I, Tohir RK, Widyaningrum Y, Prabawati U, dan Lydiasari R. 2014. Slamet,Central Java, Indonesia. BiodiKeanekaragaman Jenis Herpetofauna versitas. 16(2):196-204.

Di Jalur Cikaweni Pusat Pendidikan Konservasi Alam Bodogol (Ppkab), Resort Bodogol, Taman Nasional Gunung Gede Pangrango. Bogor(ID): Institut Pertanian Bogor. 